\title{
Intracellular chitinase gene from Rhizopus oligosporus: molecular cloning and characterization
}

\author{
Naoki Takaya, $†$ Daisuke Yamazaki, Hiroyuki Horiuchi, Akinori Ohta \\ and Masamichi Takagi
}

Department of

Biotechnology, The

University of Tokyo, Yayoi,

Bunkyo-ku, Tokyo 113,

Japan Author for correspondence: Masamichi Takagi. Tel: +81 338122111 ext. 5169. Fax: +81338129246.
e-mail: amtakag@hongo.ecc.u-tokyo.ac.jp
Multiple chitinases have been found in hyphae of filamentous fungi, which are presumed to have various functions during hyphal growth. Here it is reported, for the first time, the primary structure of one such intracellular chitinase, named chitinase III, from Rhizopus oligosporus, a zygomycete filamentous fungus. Chitinase III was purified to homogeneity from actively growing mycelia of $R$. oligosporus using three steps of column chromatography. Its molecular mass was $43.5 \mathrm{kDa}$ and the pH optimum was 6.0 when p-nitrophenyl $\boldsymbol{N}, \boldsymbol{N}^{\prime}, \boldsymbol{N}^{\prime}-\boldsymbol{\beta}$-D-triacetylchitotrioside was used as a substrate. Chitinase III also hydrolysed chromogenic derivatives of chitobiose, but had no $\mathrm{N}$ acetylglucosaminidase activity. The gene encoding chitinase III (chi3) was cloned using PCR with degenerate oligonucleotide primers from the partial amino acid sequence of the enzyme. The deduced amino acid sequence of chi3 was similar to that of bacterial chitinases and chitinases from mycoparasitic fungi, such as Aphanocladium album and Trichoderma harzianum, but it had no potential secretory signal sequence in its amino terminus. Northern blot analysis showed that chi3 was transcribed during hyphal growth. These results suggest that chitinase III may function during morphogenesis in $R$. oligosporus.

Keywords: Rhizopus oligosporus, zygomycetes, chitinase

\section{INTRODUCTION}

Chitin, a homopolymer of 1,4- $\beta$-linked $N$-acetyl-Dglucosamine, is widely distributed in invertebrates, fungi and algae and confers strength against mechanical forces from the environment as external skeletons or cell walls. In filamentous fungi, chitin is one of the major components of the cell wall and is thought to be important for maintaining cell wall integrity. Proper chitin metabolism may be essential for hyphal growth and morphology.

Chitinase (EC 3.2.1.1.14) is an enzyme which hydrolyses chitin at 1,4- $\beta$-bonds between $N$-acetylglucosamine

\footnotetext{
† Present address: Institute of Applied Biochemistry, University of Tsukuba, Ibaragi 305, Japan.

Abbreviation: PNP, p-nitrophenyl.

The DDBJ accession number for the chi3 sequence reported in this paper is D87894.
}

units. The enzyme is found in bacteria, plants, insects, humans and fungi (Flach et al., 1992; Collinge et al., 1993; Boot et al., 1995) and is thought to function in assimilation of chitin, defence against fungal pathogens and separation of dividing cells, although the actual roles of most chitinases remain to be elucidated. In filamentous fungi, chitinases are thought to be involved in processes requiring cell wall digestion (Gooday, 1990), viz. germination of spores, tip growth of hyphae (Bartnicki-Garcia, 1973), branching of hyphae, hyphal autolysis and differentiation into spores, as well as in assimilation of chitin and mycoparasitism. There have been few reports of chitinases of filamentous fungi. In Mucor rouxii, multiple chitinase activities have been observed in mycelial extracts (Rast et al., 1991) and germinating spores (Pedraza-Reyes \& Lopez-Romeo, 1991). Their roles in fungal growth and mechanisms of chitinase regulation are almost totally unknown.

Rhizopus oligosporus is a filamentous fungus that belongs to the phylum Zygomycota, whose cell walls are mainly composed of chitin and its deacetylated de- 
rivative, chitosan (Davis \& Bartnicki-Garcia, 1984). Because of the abundance of chitin and chitosan, $R$. oligosporus could be a good organism for the analysis of cell wall chitin metabolism. We have already cloned two chitin synthase genes (Motoyama et al., 1994) and also two chitinase genes, chi1 and its allelic gene chi2, encoding chitinase I and chitinase II, respectively, from this organism (Yanai et al., 1992). In the course of our study, it was revealed that chitinase I and chitinase II are induced in the late stage of culture, when the hyphae autolyse, so that we could purify the enzymes from the culture medium. It was also found that they are synthesized with $\mathrm{N}$-terminal signal sequences for secretion. These results suggest that chitinase I and II are not involved in hyphal growth.

With the aim of revealing the function of chitinases in growing hyphae, we report here the purification and characterization of chitinase III from mycelial extracts of $R$. oligosporus and the cloning of the gene encoding this enzyme. Our results suggest that chitinase III has a role during hyphal growth and that filamentous fungi have evolutionarily divergent chitinases with markedly differing roles in chitin metabolism.

\section{METHODS}

Strains and media. R. oligosporus IFO8631 was used throughout this work. $R$. oligosporus was grown in SIV (Takaya et al., 1994) or potato dextrose medium. Escherichia coli MV1190 [ $\Delta\left(\right.$ lac-proAB) thi supE $\Delta\left(\right.$ srl-recA) $306:: \operatorname{Tn} 10 \operatorname{Tet}^{r}\left(\mathrm{~F}^{\prime}\right.$ traD36 proAB lacl $\left.\left.^{\mathrm{Z} Z} \mathrm{Z} M 15\right)\right]$ was used for the propagation of plasmids. E. coli was grown in LB medium and $50 \mu \mathrm{g}$ ampicillin $\mathrm{ml}^{-1}$ was added if necessary.

Culture conditions. Surface culture was done as described previously (Yanai et al., 1992). Submerged culture was done as follows: spores (approx. $8 \times 10^{7}$ ) of $R$. oligosporus were inoculated into a 5 litre Erlenmeyer flask containing 1 litre SIV medium and cultivated in a rotary shaker at 120 r.p.m., $30^{\circ} \mathrm{C}$.

Enzyme activity assay. Chitinase assay was performed with the chromogenic substrate $p$-nitrophenyl $N, N^{\prime}, N^{\prime \prime}-\beta$-D-triacetylchitotrioside (PNP chitotrioside; Seikagaku-Kogyo). Reactions contained $0.1 \mathrm{M}$ potassium citrate $(\mathrm{pH} 6.5)$, Triton $\mathrm{X}-100(0.1 \%, \mathrm{v} / \mathrm{v}), 0.5 \mathrm{mM}$ PNP chitotrioside at $37^{\circ} \mathrm{C}$ in a total volume of $100 \mu \mathrm{l}$. The reaction was stopped with $500 \mu \mathrm{l}$ $1 \mathrm{M} \mathrm{Na}{ }_{2} \mathrm{CO}_{3}$ and the absorption of $p$-nitrophenol was spectrophotometrically determined at $415 \mathrm{~nm}$ (Hitachi U2000 spectrophotometer). One unit of enzymic activity was defined as that which released $1 \mathrm{nmol} p$-nitrophenol $\mathrm{min}^{-1}$.

Enzyme purification. Chitinase I was purified as described previously (Yanai et al., 1992). For purification of chitinase III, 12 litres SIV medium was inoculated with $10^{9}$ spores of $R$. oligosporus and incubated with shaking at $30^{\circ} \mathrm{C}$ for $18-20 \mathrm{~h}$. Mycelia ( $130 \mathrm{~g}$ wet $\mathrm{wt}$ ) were harvested by filtration, washed with $20 \mathrm{mM} \mathrm{NaHCO}_{3}(\mathrm{pH} \mathrm{8.4})$ and suspended in $600 \mathrm{ml}$ of the same buffer containing $1 \mathrm{mM}$ EDTA, $1 \mathrm{mM}$ PMSF and $10 \mathrm{mM} \beta$-mercaptoethanol. Mycelia were broken with a Waring blender at top speed. Triton X-100 was added to a final concentration of $1 \%$ and the broken mycelial mixture stirred for $3 \mathrm{~h}$ at $4{ }^{\circ} \mathrm{C}$. After centrifugation at $7000 \mathrm{~g}$ for $30 \mathrm{~min}$, the supernatant was loaded onto a regenerated-chitin column $(16 \times 70 \mathrm{~mm})$ and washed with $600 \mathrm{ml} 20 \mathrm{mM}$
$\mathrm{NaHCO}_{3}(\mathrm{pH} 8 \cdot 4)$ containing Triton X-100 (0.1\%) at a flow rate of $50 \mathrm{ml} \mathrm{h}^{-1}$. Fractions containing chitinase activity that were eluted by $20 \mathrm{mM}$ sodium acetate ( $\mathrm{pH} 3 \cdot 2$ ) containing Triton X-100 $(0 \cdot 1 \%)$ were immediately neutralized with $1 \mathrm{M}$ Tris. They were combined $(105 \mathrm{ml})$, dialysed against $20 \mathrm{mM}$ Tris $/ \mathrm{HCl}(\mathrm{pH} 8.0)$ containing Triton X-100 (0.1\%) and applied to a DEAE-Sephadex A50 column (Pharmacia) (10 $\times$ $100 \mathrm{~mm}$ ). The column was washed with $100 \mathrm{ml}$ of this buffer at a flow rate of $50 \mathrm{ml} \mathrm{h}^{-1}$ and chitinase activity eluted with a linear gradient from 0 to $500 \mathrm{mM} \mathrm{NaCl}$ in $300 \mathrm{ml}$ of the same buffer. Fractions $(84 \mathrm{ml})$ containing chitinase activity were pooled, dialysed against $1 \mathrm{mM}$ sodium phosphate, $0 \cdot 1 \%$ Triton X-100 (pH 6.8) and loaded onto a hydroxyapatite (Wako Chemicals) column $(10 \times 60 \mathrm{~mm})$. After washing with $100 \mathrm{ml} 1 \mathrm{mM} \mathrm{NaCl}, 40 \mathrm{mM}$ octyl D-glucoside (Dojindo), chitinase activity was eluted with $1 \mathrm{mM}$ sodium phosphate (pH 6.8), $40 \mathrm{mM}$ octyl D-glucoside. Fractions containing chitinase activity were pooled, dialysed against $40 \mathrm{mM}$ octylD-glucoside and used as the purified chitinase III preparation. This preparation was used for all enzyme characterization studies with chitinase III.

Subcellular fractionation. Subcellular fractionation of $R$. oligosporus was done as follows: $0.5 \mathrm{~g}$ (wet wt) of mycelia of $R$. oligosporus cultured in SIV medium containing glucose as carbon source was suspended in $5 \mathrm{ml} 50 \mathrm{mM}$ sodium phosphate $(\mathrm{pH} 7 \cdot 2)$ and broken with a Potter-Elvehjem homogenizer. Cell extracts were centrifuged at $1000 \mathrm{~g}$ for $15 \mathrm{~min}$ and the supernatant was recentrifuged at $10000 \mathrm{~g}$ for $15 \mathrm{~min}$ at $4{ }^{\circ} \mathrm{C}$ to prepare the $10000 \mathrm{~g}$ pellet. The supernatant was centrifuged at $100000 \mathrm{~g}$ for $1 \mathrm{~h}$ at $4{ }^{\circ} \mathrm{C}$ to obtain the $100000 \mathrm{~g}$ pellet and $100000 \mathrm{~g}$ supernatant.

Solubilization of proteins. Solubilization of the $10000 \mathrm{~g}$ and $100000 \mathrm{~g}$ pellets was carried out as follows: $10000 \mathrm{~g}$ or $100000 \mathrm{~g}$ pellets containing approximately $20 \mathrm{mg}$ protein were suspended in $50 \mathrm{mM}$ sodium phosphate $(\mathrm{pH} 7 \cdot 2)$ to a final volume of $4 \mathrm{ml}$. Triton $\mathrm{X}-100$ was added to a final concentration of $1 \%$ and the resuspension incubated for $1 \mathrm{~h}$ at $4{ }^{\circ} \mathrm{C}$. It was then centrifuged at $10000 \mathrm{~g}$ for $15 \mathrm{~min}$ at $4{ }^{\circ} \mathrm{C}$. The supernatants were loaded directly onto the chitin column.

SDSPAGE and Western blot analysis. SDS-PAGE was done as described by Laemmli (1970). Western blot analysis was performed with ECL-Western blotting detection reagents (Amersham) according to the manufacturer's instructions.

Protein sequencing. In situ digestion of chitinase III was done essentially according to the method of Aebersold et al. (1987). Chitinase III (about $60 \mu \mathrm{g}$ ) was subjected to SDS-PAGE and transferred by blotting to nitrocellulose membrane (Schleicher \& Schuell). The protein bands were detected by staining with Ponceau S (Sigma) and a protein of $43.5 \mathrm{kDa}$ excised and digested with trypsin. The tryptic fragments were separated by C18 reverse-phase HPLC and the amino terminal sequences of three of these fragments (P15, P32 and P34) determined using an automated amino acid sequencer (Applied Biosystems model 373A).

Isolation of the chi3 gene. $R$. oligosporus total DNA, prepared as described previously (Horiuchi et al., 1988), was used as a template for PCR with the following degenerate oligonucleotide primers: $31,5^{\prime}$ GGCATNCCNACNAC 3' (corresponding to the sequence of tryptic peptide P32); and 32, $5^{\prime}$ TTYGCNAAYGTNCARCC $3^{\prime}$ and $33,5^{\prime}$ ATRTCNGCRTANGCRTC 3' (both corresponding to the sequence of tryptic peptide $\mathrm{P} 34$. N, Y and $\mathrm{R}$ indicate any of the four nucleotides, a pyrimidine and a purine, respectively). The first PCR was done with primer 31 (100 pmol), primer 32 
(100 pmol) and $0.5 \mu \mathrm{g}$ total DNA as a template. Cycling conditions were: $10 \mathrm{~min}$ at $94^{\circ} \mathrm{C}$ for the first denaturation; 30 cycles of $0.5 \mathrm{~min}$ at $94{ }^{\circ} \mathrm{C}, 1 \mathrm{~min}$ at $42^{\circ} \mathrm{C}$ and $2 \mathrm{~min}$ at $72{ }^{\circ} \mathrm{C}$ for amplification; then $10 \mathrm{~min}$ at $72{ }^{\circ} \mathrm{C}$ for extension. Products of about $700 \mathrm{bp}$ were purified by agarose gel electrophoresis and used as a template for the second PCR. The second PCR was performed using the same conditions except for the use of primers 32 and 33. An amplified DNA fragment of the expected size was obtained and purified. Labelled probes were prepared using $\left[\alpha^{32} \mathrm{P}\right] \mathrm{dCTP}$ by the random primer labelling method (Feinberg \& Vogelstein, 1983) and used for screening of a genomic library constructed in vector $\lambda 2001$ (Yanai et al., 1992) by plaque hybridization (Sambrook et al., 1989).

Nucleotide sequencing. A $3.8 \mathrm{~kb}$ Sall-PstI fragment bearing the chi3 gene was inserted into pUC119 and a series of deletions generated using exonuclease III and mung bean nuclease. The truncated chi3 DNAs were sequenced by the dideoxy chain-termination method (Sanger et al., 1977). In some cases, restriction fragments of the chi3 DNA were cloned into pUC119 and sequenced. Primer extension analysis was done as described by Rothmel \& LeClerc (1989) using the oligonucleotide 5' CAGGTCCGTTTGTTGCTGGAGGTGGTTCC $3^{\prime}$ as a primer.

RNA analysis. Spores of $R$. oligosporus $\left(10^{5} \mathrm{ml}^{-1}\right)$ were cultured in SIV medium containing glucose $(2 \%, \mathrm{w} / \mathrm{v})$ at $30{ }^{\circ} \mathrm{C}$ for $24 \mathrm{~h}$. Mycelia were then transferred to SIV medium containing no carbon source, $0 \cdot 1 \%$ glucose, $2 \%$ glucose, or $10 \%(\mathrm{w} / \mathrm{v})$ colloidal chitin (Yanai et al., 1992) and incubated at $30^{\circ} \mathrm{C}$ for $24 \mathrm{~h}$. Total RNA was prepared from the mycelia using the RNeasy Total RNA kit (Qiagen) according to the manufacturer's instructions. Thirty micrograms of each RNA preparation were separated by agarose gel electrophoresis, blotted to Hybond-N (Amersham) and hybridized with the $[\alpha-$ ${ }^{32} \mathrm{P}$-labelled chi3 cDNA fragment as a probe. Signals were detected using a Bioimaging Analyzer BAS2000 (Fuji Photo Film).

\section{RESULTS}

\section{Purification of chitinase III}

To purify intracellular chitinase in the present study, we used actively growing hyphae of $R$. oligosporus as starting material, in contrast to our previous work (Yanai et al., 1992). Mycelial homogenates were extracted with buffer containing Triton X-100 (1\%) and the soluble fraction was subjected to a series of column chromatography procedures. During the first regenerated-chitin column chromatography step, significant activity was eluted as a single peak with $20 \mathrm{mM}$ acetate $(\mathrm{pH} 3 \cdot 2)$ containing Triton $\mathrm{X}-100(0 \cdot 1 \%)$ and was subjected to further purification. As no activity was eluted with the buffer lacking Triton X-100, the detergent was included in the buffer in the following steps. During DEAE-Sephadex chromatography, the enzyme activity was eluted as a broad peak from $100 \mathrm{mM}$ to $400 \mathrm{mM} \mathrm{NaCl}$ concentration. This step had little effect on purification, but was helpful for concentrating the enzyme activity in the following final step. By the procedure described, we purified the chitinase activity by 2400 -fold with a yield of $1.3 \%$ from the detergentsoluble fraction of mycelia. SDS-PAGE of this fraction showed a single band of molecular mass of $43.5 \mathrm{kDa}$

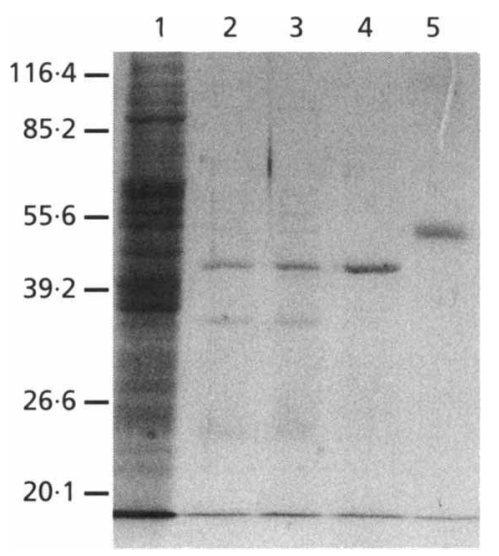

Fig. 1. Analysis of protein profiles during chitinase III purification procedure. Approximately $30 \mu \mathrm{g}$ protein (lane 1) or $2 \mu \mathrm{g}$ protein (lanes $2-5$ ) were separated on a $10 \%$ SDS-PAGE gel and visualized by Coomassie brilliant blue staining. Molecular mass standards are indicated in $\mathrm{kDa}$. Lanes: 1 , crude $1 \%$ Triton X-100 extract; $2,20 \mathrm{mM}$ sodium acetate eluate from regenerated-chitin column; 3, pool from DEAE-Sephadex A50 column; 4, pool from hydroxyapatite column; 5, purified chitinase I.

(Fig. 1, lane 4) and we designated this protein chitinase III. A summary of the representative purification steps is shown in Table 1.

\section{Characterization of the purified enzyme}

The isoelectric point of chitinase III was approximately $7 \cdot 0$ (data not shown). No positive signal was obtained by periodic acid/Schiff reagent staining (Poehling \& Neuhoff, 1981) after SDS-PAGE (data not shown). This was consistent with the lack of consensus sequences for asparagine-linked glycosylation in the deduced amino acid sequence (see below), suggesting that chitinase III has no glycosyl chain. The optimum $\mathrm{pH}$ for enzyme activity with PNP chitotrioside as substrate was approximately $6 \cdot 0$, which is much higher than that for chitinase I (optimum pH 3.0), another chitinase purified from this fungus (Yanai et al., 1992) (data not shown). The specific activity for PNP chitotrioside was $19.8 \mathrm{U}(\mathrm{mg}$ protein $)^{-1}$, which was $8 \cdot 9$-fold lower than that of chitinase I. The specificity of each chitinase for chromogenic chitooligoside substrates was determined. The activity of chitinase III with PNP chitobioside or PNP chitotetraoside as substrate was approximately one-fifth and sevenfold that for PNP chitotrioside, respectively, whilst the activity of chitinase I with PNP chitobioside or PNP chitotetraoside as substrate was below onefiftieth and 10-fold that for PNP chitotrioside, respectively (experiments were undertaken three times with the same results, data not shown). $K_{\mathrm{m}}$ values of chitinase III and chitinase I for PNP chitotrioside were $7.8 \times 10^{-5} \mathrm{M}$ and $1.3 \times 10^{-4} \mathrm{M}$, respectively. The $K_{\mathrm{i}}$ of chitinase III for allosamidin, a competitive inhibitor of chitinases, was $3.0 \times 10^{-8} \mathrm{M}$, which was one-sixth that of chitinase I $\left(1 \cdot 8 \times 10^{-7} \mathrm{M}\right) . \mathrm{MnCl}_{2}(1 \mathrm{mM})$ increased the activity of 
Table 1. Purification of chitinase III from mycelial extract of $R$. oligosporus

Data from a typical purification procedure are presented. Three independent isolation experiments gave comparable results.

\begin{tabular}{|lccccc|}
\hline Purification step & $\begin{array}{c}\text { Protein } \\
(\mathbf{m g})\end{array}$ & $\begin{array}{c}\text { Total activity } \\
(\mathbf{U})\end{array}$ & $\begin{array}{c}\text { Specific activity } \\
{\left[\mathbf{U}(\mathbf{m g} \text { protein })^{-1}\right]}\end{array}$ & $\begin{array}{c}\text { Yield } \\
(\%)\end{array}$ & $\begin{array}{c}\text { Purification } \\
\text { (-fold) }\end{array}$ \\
\hline Crude extract & 7728 & $64000 \cdot 0$ & $8 \cdot 28$ & 100 & $1 \cdot 0$ \\
Regenerated chitin & 1.56 & $5950 \cdot 0$ & $3814 \cdot 1$ & $9 \cdot 3$ & $460 \cdot 6$ \\
DEAE-Sephadex & 0.80 & $1182 \cdot 1$ & $1477 \cdot 5$ & $2 \cdot 0$ & 178.4 \\
Hydroxyapatite & 0.043 & $853 \cdot 3$ & $19844 \cdot 2$ & $1 \cdot 3$ & $2396 \cdot 6$ \\
\hline
\end{tabular}

chitinase III $2 \cdot 7$-fold, but had no effect on chitinase I. The metal ion chelator (10 mM EDTA) had no effect on chitinase III activity, but inhibited chitinase I activity by approximately $50 \%$. The activities of these chitinases were not affected significantly by DTT $(10 \mathrm{mM}), \beta$ mercaptoethanol $(10 \mathrm{mM}), \mathrm{MgCl}_{2}(1 \mathrm{mM}), \mathrm{CaCl}_{2}$ (1 mM), $\mathrm{ZnCl}_{2}(1 \mathrm{mM}), \mathrm{NaMoO}_{4}(1 \mathrm{mM})$ or $\mathrm{CoCl}_{2}$ (1 mM) (data not shown).

A preliminary result suggested that the activity of chitinase III increased in the presence of Triton X-100 $(0 \cdot 1 \%)$ and this may be indicative of association with other macromolecules or membranes. Therefore, we examined the effects of the detergent, a phospholipid and serum albumin on enzyme activity. The results showed that activity of the purified enzyme increased approximately fourfold in the presence of each of Triton $\mathrm{X}-100(0 \cdot 1 \%)$, serum albumin $\left(1 \mu \mathrm{g} \mathrm{ml}^{-1}\right)$ or phosphatidylcholine $\left(1 \mu \mathrm{g} \mathrm{ml}^{-1}\right)$ (data not shown).

\section{Intracellular localization of chitinase III}

We investigated the distribution of chitinase III in $R$. oligosporus by Western blot analysis of a few subcellular fractions using antibody, raised against Bacillus circulans chitinase A1, which did not react with chitinase I or II. Using this antibody, only a single protein band of $43.5 \mathrm{kDa}$ was detected following Western blot analysis of the fraction, eluted from the chitin column during enzyme purification, that contained chitinase III activity. We added Triton X-100 to each of the $10000 \mathrm{~g}$ and $100000 \mathrm{~g}$ pellet fractions (final concentration, $1 \%$ ) to solubilize the pellet (see Methods section), purified chitinase activity from these and the $100000 \mathrm{~g}$ supernatant fraction using the regenerated-chitin column, and carried out Western blot analysis with anti-chitinase A1 antiserum (Fig. 2). Chitinase III was detected in both $100000 \mathrm{~g}$ supernatant and $10000 \mathrm{~g}$ pellet fractions. These results suggest that some portion of chitinase III is associated with membrane- or cell-wall structures in $R$. oligosporus.

\section{Amino acid sequencing of chitinase III}

Direct sequencing of the amino-terminal amino acids of chitinase III was unsuccessful. Therefore, three tryptic peptides of chitinase III (P15, P32 and P34) were sequenced. The amino acid sequences of P15, P32 and

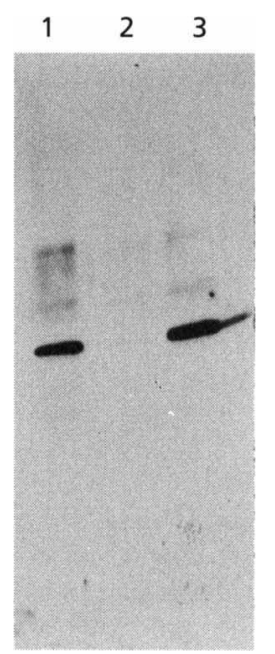

Fig. 2. Western blot analysis of subcellular fractions of $R$. oligosporus lysate. Approximately $1.0 \mu \mathrm{g}$ protein per lane was transferred to nitrocellulose and incubated with anti-chitinase A1 antiserum. Lanes: 1, solubilized $10000 \mathrm{~g}$ pellet; 2, solubilized $100000 \mathrm{~g}$ pellet; $3,100000 \mathrm{~g}$ supernatant.

P34 were YNVVDVATQANK, LVVGMPLYGR and AFANVQPDGQVVLGDAYADI, respectively. Searching the protein databases (SWISS-PROT and PIR), we found that peptide P32 had similarity to chitinase 1 of Aphanocladium album ( 7 of 10 amino acid positions were identical) (Blaiseau \& Lafay, 1992) and chitinase A1 of $B$. circulans ( 8 of 10 amino acid positions were identical) (Watanabe et al., 1990). Peptide P34 also had similarity to the A. album chitinase (10 of 20 amino acid positions were identical), whilst peptide P15 showed no significant homology to known sequences.

\section{Cloning of the chitinase-Ill-encoding gene}

To clone the gene encoding chitinase III, nested PCR (McPherson et al., 1995) was performed with three degenerate oligonucleotide primers based on the sequences of peptides P32 and P34. The nucleotide sequence of a specifically amplified $0.11 \mathrm{~kb}$ fragment was determined and its deduced amino acid sequence completely matched the sequence of P34, if we assumed 
$P A \subset G T$

(a)

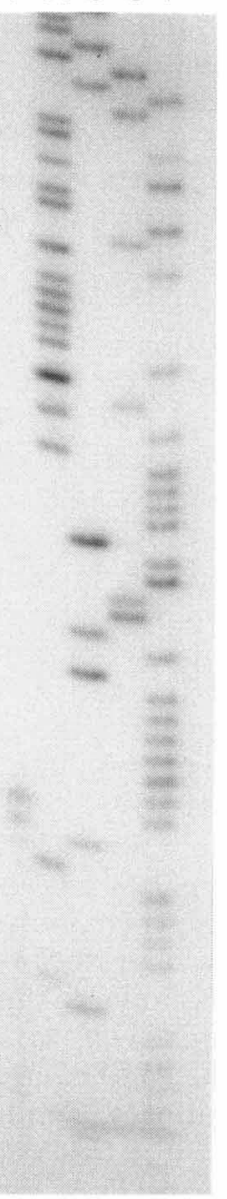

(b)

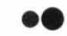

TTTTCATTTTACTTTTCTTGACTTCTCATATG

Fig. 3. Primer extension analysis of $R$. oligosporus chi3. (a) Lanes $A, C, G$ and $T$ indicate profiles of DNA sequences assayed by the dideoxy method. Lane $P$, products of primer extension reaction. Transcription start sites are shown by dots on the left. (b) Transcription start sites and the translation initiation site are indicated by dots and box, respectively.

an intron between the fourteenth amino acid (glycine)and fifteenth amino acid (aspartic acid)-encoding sequences. A genomic DNA library was screened using this DNA fragment as a hybridization probe and four positive clones were obtained. They were divided into two classes by their restriction maps. A $3.8 \mathrm{~kb}$ Sall-Pst I fragment from one of the positive clones was inserted into pUC119 and its nucleotide sequence was determined. One ORF containing three putative intron sequences was present and its deduced amino acid sequence contained sequences that matched peptides P15, P32 and P34.

Since the transcription start site was at the twentyseventh $T$, as determined by the primer extension method (Fig. 3a), the translation initiation site was (a)

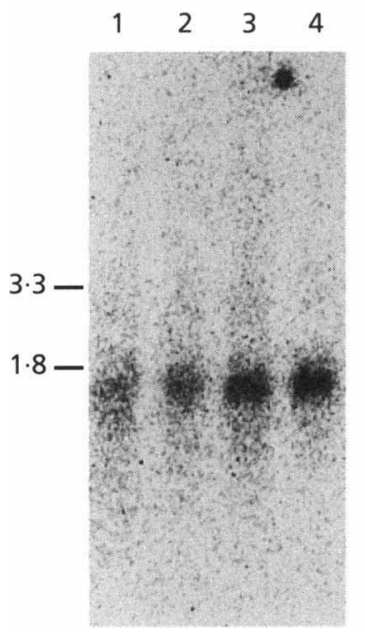

(b)

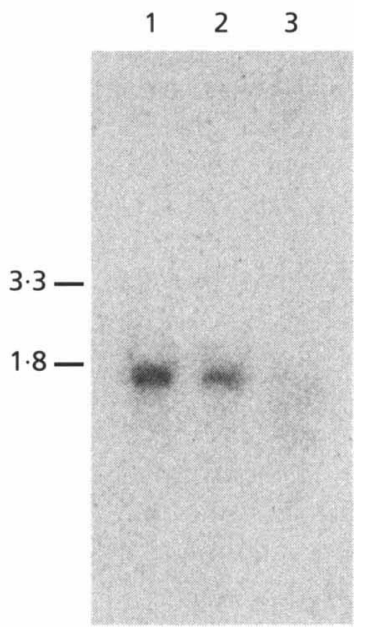

Fig. 4. Northern blot analysis using chi3 CDNA as hybridization probe. (a) $R$. oligosporus was cultured in SIV medium containing glucose as carbon source for $24 \mathrm{~h}$ at $30^{\circ} \mathrm{C}$, then transferred to SIV medium containing one of the following carbon sources: none (lane 1); glucose (0.1\%) (lane 2); glucose (2\%) (lane 3); colloidal chitin (10\%) (lane 4) and incubated for $24 \mathrm{~h}$ at $30^{\circ} \mathrm{C}$ (Yanai et al., 1992). RNA was isolated as described in the text and $30 \mu \mathrm{g}$ RNA electrophoresed per lane. (b) Total RNA was prepared from submerged culture in SIV medium containing glucose $(2 \%)$ as sole carbon source after $24 \mathrm{~h}$ (lane 1), surface culture on the same medium after $24 \mathrm{~h}$ (lane 2) and surface culture after $48 \mathrm{~h}$ (lane 3 ). RNA was isolated and electrophoresed as described above. Positions of rRNAs are shown on the left in $\mathrm{kb}$.

assigned as shown in Fig. 3(b). The presence of the introns was confirmed by the sequence of the cDNA of chi3 (data not shown). These results indicated that this DNA fragment contained the chitinase-III-encoding gene, which was designated chi3. The predicted amino acid sequence was comprised of 400 amino acids and its calculated molecular mass was $44.9 \mathrm{kDa}$, which corresponds well to that of chitinase III. There is neither a potential secretory signal sequence in its amino terminus nor a long hydrophobic stretch in the internal sequence. The partial nucleotide sequence of another clone with a different restriction map was also determined. Its deduced amino acid sequence was very similar to that of chitinase III (data not shown), suggesting that this clone could contain an allele of chi3, which is consistent with the observation that $R$. oligosporus is diploid or aneuploid (Motoyama et al., 1994; Yanai et al., 1992).

\section{Homology to other chitinases}

Although there is no potential secretory signal sequence, the amino acid sequence of chitinase III is similar to a number of sequences reported previously for chitinases, demonstrating $42,42,42,42,40$ and $25 \%$ similarity to A. album chitinase 1 (Blaiseau \& Lafay, 1992), Trichoderma harzianum ThEn-42 chitinase (Hayes et al., 1994), T. harzianum ECH-42 chitinase (Carsolio et al., 1994), T. harzianum CHIT42 chitinase (García et al., 1994), 
Coccidioides immitis CTS1 chitinase (Pishko et al., 1995) and B. circulans chitinase A1 (Watanabe et al., 1990), respectively. A. album chitinase 1 and $T$. harzianum $\mathrm{ECH}-42$ chitinase have been reported to be similar to bacterial chitinases. On the other hand, chitinase III has very limited similarity to yeast chitinases (Kuranda \& Robbins, 1991; McCreath et al., 1995) or to chitinase I and chitinase II of $R$. oligosporus (Yanai et al., 1992), except for short conserved sequences $(+101$ LSIGG +105 and +139 DGLDIDWE + 146; the numbers represent amino acid residues from the amino terminus of chitinase III), which are known to be important for catalytic activity (Watanabe et al., 1993). These results indicate that chitinase III belongs to the bacterial-type chitinase subclass rather than to the fungal-type chitinase subclass of yeasts and filamentous fungi.

\section{Expression of chi3 mRNA in R. oligosporus}

Northern blot analysis was performed using chi3 cDNA as a hybridization probe. chi3 mRNA was abundant in actively growing cells and was not increased by addition of colloidal chitin (Fig. 4a). It was reduced when the mycelia were transferred to a medium which contained only a low concentration of carbon or no carbon source. Furthermore, chi3 mRNA was not detected during the late stage of surface culture (Fig. 4b, lane 3), under conditions where chitinase I was produced in abundance (data not shown), indicating that the expression of chi3 and of chi1 is regulated differently during growth.

\section{DISCUSSION}

In this study, we have purified and characterized intracellular chitinase III from the mycelial extract of $R$. oligosporus, cloned its encoding gene and analysed the structure of the gene. This is the first report of the isolation of the gene encoding an intracellular chitinase from a filamentous fungus. The optimum $\mathrm{pH}$ for enzyme activity was nearly neutral and higher than that of extracellular chitinase I, suggesting that chitinase III may function in the cytosol. The deduced amino acid sequence of chitinase III had no potential secretory signal sequence and no possible sequence for modification by carbohydrate chains commonly found in secretory proteins. Interestingly, its deduced amino acid sequence indicates that it belongs to the bacterial-type chitinase subgroup rather than the fungal-type subgroup, in spite of the fact that the bacterial-type chitinases reported so far have hydrophobic residues in their amino termini and are known to be extracellular proteins. It is possible that there is another intracellular chitinase in $R$. oligosporus which does not bind to the chitin column under our experimental conditions since a substantial part of the total chitinase activity was detected in the unbound fraction during chitin column chromatography.

Chitinase III exhibited a higher affinity than chitinase I for small chitooligosides. Chitinase I has a serine/ threonine-rich domain and a chitin-binding domain on the carboxy terminus, which have been suggested to act as acceptor sites for O-glycosylation and high-affinity chitin binding, respectively (Kuranda \& Robbins, 1991). In contrast, chitinase III had no such domains. This difference may be related to the varying substrate specificity of the two enzymes and to the different chitinase subgroups they belong to, since the bacterialtype chitinase (Chit42) from $T$. harzianum cleaves smaller oligomers of chitin than the fungal-type chitinase (Chit33) (De la Cruz et al., 1992).

In the subcellular fractionation experiment, significant amounts of chitinase III were detected in the $10000 \mathrm{~g}$ pellet, which could be solublized in the presence of Triton X-100, and the activity of this enzyme was stimulated by Triton X-100, serum albumin and phospholipid. These results suggest that chitinase III could be most active in the cells in contact with membrane- or cell-wall structures. In M. rouxii and Candida albicans cell extracts the presence of membrane-bound chitinases is suggested and the activities of these enzymes are inhibited by treatment with phospholipases and stimulated by detergents (Humphreys \& Gooday, 1984; Dickinson et al., 1991). A $45 \mathrm{kDa}$ chitinase was purified from the cytosolic fraction of $C$. albicans. The enzyme has an optimum $\mathrm{pH}$ of 5.0 and chitinase activity was stimulated 1.5-fold when phosphatidylcholine was present in the reaction mixtures (Mellor et al., 1994). These characteristics are similar to those of chitinase III studied during the present investigation. We are interested in the possibility that the $45 \mathrm{kDa}$ chitinase of C. albicans is a bacterial-type chitinase, similar to those detected in filamentous fungi, which has not so far been detected in yeasts. In this regard it is important to note that $C$. albicans is a dimorphic fungus capable of filamentous growth.

The expression pattern of chi3 suggests that the enzyme is produced during hyphal growth. Chitinases are thought to be involved in hyphal tip growth and branching. It is possible that chitinase III may function in loosening the cell wall at the hyphal tip to enable turgor pressure to extend the hypha at the apex (Bartnicki-Garcia, 1973). Rast et al. (1991) proposed a model for functional relationships between chitinases and chitin synthases. According to this model, there are two types of chitinases in mycelia of $M$. rouxii. The type A chitinases, which hydrolyse smaller chitooligosides efficiently, are proposed to provide $N$-acetylglucosamine to activate chitin synthase(s) allosterically. The other, type B chitinases, are speculated to provide substrates for type A chitinases by hydrolysing long-chain cell wall chitin. Our results suggest that chitinase III hydrolyses well small chitooligosides rather than large ones and could interact with membrane- or cell-wall structures in the cell, proposals which are compatible with the ideas of Rast et al. (1991) described above. Stimulation of chitinase activity by $\mathrm{Mn}^{2+}$, as observed during the present study, has also been reported for some chitin synthases (Sudoh et al., 1995).

Recently, both fungal- and bacterial-type chitinase genes were cloned from each of two fungi: T. harzianum (Carsolio et al., 1994; García et al., 1994; Hayes et al., 
1994; Limón et al., 1995) and C. immitis (Pishko et al., 1995). We also cloned both types of chitinase genes (chiA and chiB) from Aspergillus nidulans (Takaya et at., 1998; unpublished results). In T. harzianum, the expression of Chit42 is induced by chitin in the culture medium. In contrast, $R$. oligosporus chitinase I (unpublished results) and chitinase III are not induced by chitin. It is probable that the genes encoding these two different types of chitinase evolved before these fungi diverged from their common ancestor, and that differing gene-regulating mechanisms have evolved in different fungi living in different environments.

\section{ACKNOWLEDGEMENTS}

We are grateful to Dr S. Sakuda and Dr T. Watanabe for providing allosamidin and anti-chitinase $\mathrm{A} 1$ antiserum, respectively. We are also grateful to Dr S. Nakajo and Dr K. Nakaya for the amino acid sequencing analysis of chitinase III. This study was supported by a Grant-in-Aid for Scientific Research from the Ministry of Education, Science and Culture of Japan. This work was performed using the facilities of the Biotechnology Research Center, The University of Tokyo.

\section{REFERENCES}

Aebersold, R. H., Leavitt, J., Saavedra, R. A., Hood, L. E. \& Kent, S. B. H. (1987). Internal amino acid sequence analysis of proteins separated by one- or two-dimensional gel electrophoresis after in situ protease digestion on nitrocellulose. Proc Natl Acad Sci USA 84, 6970-6974.

Bartnicki-Garcia, S. (1973). Fundamental aspects of hyphal morphogenesis. In Microbial Differentiation, pp. 245-267. Edited by J. M. Ashworth \& J. E. Smith. Cambridge: Cambridge University Press.

Blaiseau, P.-L. \& Lafay, J. (1992). Primary structure of a chitinaseencoding gene (chi1) from the filamentous fungus Aphanocladium album: similarity to bacterial chitinases. Gene 120, 243-248.

Boot, R. G., Renkema, G. H., Strijland, A., van Zonneveld, A. J. \& Aerts, J. M. F. G. (1995). Cloning of a cDNA encoding chitotriosidase, a human chitinase produced by macrophages. I Biol Chem 270, 26252-26256.

Carsolio, C., Gutiérrez, A., Jiménez, B., Montagu, M. V. \& HerreraEstrella, A. (1994). Characterization of ech-42, a Trichoderma harzianum endochitinase gene expressed during mycoparasitism. Proc Natl Acad Sci USA 91, 10903-10907.

Collinge, D. B., Kragh, K. M., Mikkelesen, J. D., Nielsen, K. K., Rasmussen, U. \& Vad, K. (1993). Plant chitinases. Plant J 3, 31-40.

Davis, L. L. \& Bartnicki-Garcia, S. (1984). Chitosan synthesis by the tandem action of chitin synthase and chitin deacetylase from Mucor rouxii. Biochem J 23, 1065-1068.

De la Cruz, J., Hidalgo-Gallego, A., Lora, J. M., Benítez, T. \& Pintor-Toro, J. A. (1992). Isolation and characterization of three chitinases from Trichoderma harzianum. Eur J Biochem 206, 859-867.

Dickinson, K., Keer, V., Hitchcock, C. A. \& Adams, D. J. (1991). Microsomal chitinase activity from Candida albicans. Biochim Biophys Acta 1073, 177-182.

Feinberg, A. P. \& Vogelstein, B. (1983). A technique for radiolabeling DNA restriction endonuclease fragments to high specific activity. Anal Biochem 137, 266-267.

Flach, J., Pilet, P.-E. \& Jollès, P. (1992). What's new in chitinase research? Experientia 48, 701-716.
García, I., Lora, J. M., de la Cruz, J., Benitez, T., Lobell, A. \& PintorToro, J. A. (1994). Cloning and characterization of a chitinase (CHIT42) cDNA from the mycoparasitic fungus Trichoderma harzianum. Curr Genet 27, 83-89.

Gooday, G. W. (1990). Physiology of microbial degradation of chitin and chitosan. Biodegradation 1, 177-190.

Hayes, C. K., Klemsdal, S., Lorito, M., Pietro, A. D., Peterbauer, C., Nakas, J. P., Tronsmo, A. \& Harman, G. E. (1994). Isolation and sequence of an endochitinase-encoding gene from a CDNA library of Trichoderma harzianum. Gene 138, 143-148.

Horiuchi, H., Yanai, K., Okazaki, T., Takagi, M. \& Yano, K. (1988). Isolation and seqencing of a genomic clone encoding aspartic proteinase of Rbizopus niveus. J Bacteriol 170, 272-278.

Humphreys, A. M. \& Gooday, G. W. (1984). Properties of chitinase activities from Mucor mucedo: evidence for a membrane-bound zymogenic form. J Gen Microbiol 130, 1359-1366.

Kuranda, M. J. \& Robbins, P. W. (1991). Chitinase is required for cell separation during growth of Saccharomyces cerevisiae. J Biol Chem 266, 19758-19767.

Laemmli, U. K. (1970). Cleavage of structural proteins during the assembly of the head of bacteriophage T4. Nature 227, 680-685.

Limón, M. C., Lora, J. M., García, I., de la Cruz, J., Llobell, A., Benítez, T. \& Pintor-Toro, J. A. (1995). Primary structure and expression pattern of the $33-\mathrm{kDa}$ chitinase gene from the mycoparasitic fungus Trichoderma harzianum. Curr Genet 28 , $478-483$.

McCreath, K. J., Specht, C. A. \& Robbins, P. W. (1995). Molecular cloning and characterization of chitinase genes from Candida albicans. Proc Natl Acad Sci USA 92, 2544-2548.

McPherson, M. J., Hames, B. D. \& Taylor, G. R. (1995). PCR 2. A Practical Approach. New York: Oxford University Press.

Mellor, K. J., Nicholas, R. O. \& Adams, D. J. (1994). Purification and characterization of chitinase from Candida albicans. FEMS Microbiol Lett 119, 111-118.

Motoyama, T., Sudoh, M., Horiuchi, H., Ohta, A. \& Takagi, M. (1994). Isolation and characterization of two chitin synthase genes of Rhizopus oligosporus. Biosci Biotechnol Biochem 58, 1685-1693.

Pedraza-Reyes, M. \& Lopez-Romeo, E. (1991). Detection of nine chitinase species in germinating cells of Mucor rouxii. Curr Microbiol 22, 43-46.

Pishko, E. J., Kirkland, T. N. \& Cole, G. T. (1995). Isolation and characterization of two chitinase-encoding genes $(c t s 1, c t s 2)$ from the fungus Coccidioides immitis. Gene 167, 173-177.

Poehling, H. \& Neuhoff, V. (1981). Visualization of proteins with a silver "stain": a critical analysis. Electrophoresis 2, 141-147.

Rast, D. M., Horsch, M., Furter, R. \& Gooday, G. W. (1991). A complex chitinolytic system in exponentially growing mycelium of Mucor rouxii: properties and function. J Gen Microbiol 137 , 2797-2810.

Rothmel, R. K. \& LeClerc, J. E. (1989). Mutational analysis of the lac regulatory region: second-site changes that activate mutant promoters. Nucleic Acids Res 17, 3909-3926.

Sambrook, J., Fritsch, E. F. \& Maniatis, T. (1989). Molecular Cloning: a Laboratory Manual, 2nd edn. Cold Spring Harbor, NY: Cold Spring Harbor Laboratory.

Sanger, F., Nicklen, S. \& Coulson, A. R. (1977). DNA sequencing with chain-terminating inhibitors. Proc Natl Acad Sci USA 74, 5463-5467.

Sudoh, M., Watanabe, M., Mio, T., Nagahashi, S., YamadaOkabe, H., Takagi, M. \& Arisawa, M. (1995). Isolation of 
canCHS1A, a variant gene of Candida albicans chitin synthase. Microbiology 141, 2673-2679.

Takaya, N., Yanai, K., Horiuchi, H., Ohta, A. \& Takagi, M. (1994). Cloning and characterization of two 3-phosphoglycerate kinase genes of Rhizopus niveus and heterologous gene expression using their promoters. Curr Genet 25, 524-530.

Takaya, N., Ymazaki, D., Horiuchi, H., Ohta, A. \& Takagi, M. (1998). Cloning and characterization of a chitinase-encoding gene (chiA) from Aspergillusn nidulans, disruption of which decreases germination frequency and hyphal growth. Biosci Biotechnol Biochem 62, 60-65.

Watanabe, T., Suzuki, K., Oyanagi, W., Ohnishi, K. \& Tanaka, H. (1990). Gene cloning of chitinase A1 from Bacillus circulans WL12 revealed its evolutionary relationship to Serratia chitinase and to type III homology units of fibronectin. J Biol Chem 265, 15659-15665.

Watanabe, T., Kobori, K., Miyashita, K., Fujii, T., Sakai, H., Uchida, M. \& Tanaka, H. (1993). Identification of glutamic acid 204 and aspartic acid 200 in chitinase A1 of Bacillus circulans WL-12 as essntial residues for chitinase activity. J Biol Chem 268, 1856718572.

Yanai, K., Takaya, N., Kojima, N., Horiuchi, H., Ohta, A. \& Takagi, M. (1992). Purification of two chitinases from Rhizopus oligosporus and isolation and sequencing of the encoding genes. $J$ Bacteriol 174, 7398-7406.

Received 24 March 1998; revised 7 May 1998; accepted 14 May 1998. 